Article

\title{
Linking Soil Properties to Climate Change Mitigation and Food Security in Nepal
}

\author{
Him L. Shrestha ${ }^{1, *}$, Trishna S. Bhandari ${ }^{2}$, Bhaskar S. Karky ${ }^{2}$ and Rajan Kotru ${ }^{2}$ \\ 1 Ministry of Population and Environment, Government of Nepal, Kathmandu 44600, Nepal \\ 2 International Centre for Integrated Mountain Development, Lalitpur 44700, Nepal; \\ Trishna.Bhandari@icimod.org (T.S.B.); bhaskar.karky@icimod.org (B.S.K.); Rajan.Kotru@icimod.org (R.K.) \\ * Correspondence: hlshrestha@gmail.com; Tel.: +977-984-130-2139
}

Academic Editor: Yu-Pin Lin

Received: 31 December 2016; Accepted: 28 March 2017; Published: 2 April 2017

\begin{abstract}
Crop productivity is directly dependent on soil fertility. High organic carbon content in soil is vital as it leads to improved soil quality, increased productivity, and stable soil aggregates. In addition, with the signing of the climate agreement, there is growing interest in carbon sequestration in landscapes. This paper looks at how soil organic carbon (SOC) can be increased so that it contributes not only to the reduction of atmospheric $\mathrm{CO}_{2}$, but also translates to the increased food production, thereby enhancing food security. This synergy between climate change mitigation and enhancing food security is even more relevant for mountain landscapes of the Hindu Kush Himalayan $(\mathrm{HKH})$ region where there remains huge potential to increase $\mathrm{CO}_{2}$ sequestration and simultaneously address food security in the chronic food deficit villages. Soil samples were collected from seven transects each in Bajhang and Mustang and from four land use types in each transect. Samples of soils were taken from two depths in each plot: $0-15 \mathrm{~cm}$ and $15-30 \mathrm{~cm}$ below the soil surface to compare the top soil and subsoil dynamics of the soil nutrients. The lab analysis was performed to assess the soil texture, soil acidity in "power of hydrogen" $(\mathrm{pH})$, and macro-nutrients reflecting soil fertility. Secondary data was used to analyze the level of food deficit in the villages. The $\mathrm{pH}$ value of soil from Bajhang ranged from 5.3 to 9.1. The $\mathrm{pH}$ value of soil ranged from 5.7 to 8.8 in Mustang. SOC contents of sampled soils from Bajhang ranged from $0.20 \%$ to $7.69 \%$ with a mean amount of $2.47 \% \pm 0.17 \%$. SOC contents of sampled soils from Mustang ranged from $0.51 \%$ to $8.56 \%$ with a mean amount of $2.60 \% \pm 0.25 \%$. By land use type, forest land had the highest carbon (C) content of $53.61 \mathrm{t} \cdot \mathrm{ha}^{-1}$ in Bajhang, whereas in Mustang, agricultural land had the highest $\mathrm{C}$ content of 52.02 tons $\cdot \mathrm{ha}^{-1}$. Based on these data, we can say that there is potential for increasing SOC through improved soil health and crop production holistic soil management should be practiced for higher productivity, and incorporating livestock for farmyard manure would fertilize cultivated soils, which increases soil productivity. Increasing productivity would aid in enhancing the access and availability of food in these mountain villages.
\end{abstract}

Keywords: crop production; soil management; soil organic carbon; soil productivity

\section{Introduction}

It is estimated that about 2500 Giga tons (Gt) of carbon (C) stored in soils worldwide is twice the amount that is stored in all terrestrial plants in the form of organic $\mathrm{C}$ which is a major source of greenhouse gases (GHGs) [1]. The soil pool is about 3.3 times the size of the atmospheric pool (760 Gt) and about 4.5 times the size of the biotic pool $(560 \mathrm{Gt})$ [1]. $C$ sequestration has the potential to offset around $5 \%-15 \%$ of global fossil fuel emissions [2]. It has been reported that the average soil organic carbon (SOC) level in South and Southeast Asia is $8.7 \mathrm{~kg} / \mathrm{m}^{2}$ which is considerably lower than the global average of $11.3 \mathrm{~kg} / \mathrm{m}$ [2]. Also the production of major cereal crops in Nepal has been 
virtually stagnant for over the past $15-20$ years and the productivity of these crops is well below those of its neighboring countries [3]. The main reasons for the low yield are believed to be the lack of replenishment of SOC and the inadequate and inappropriate use of fertilizers [4-6].

According to the Ministry of Agricultural Development (MoAD), the World Food Program of the United Nations (UNWFP) and the Food and Agriculture Organization (FAO), in Nepal, 40 districts out of 75 are food-insecure, with far and mid-western regions, in particular, being more vulnerable [7]. Food systems also have enormous potential to mitigate climate change, however, particularly at the production end of the food chain. Moreover, many of the most effective mitigation measures also represent highly effective adaptation strategies, especially for commercial agriculture. Investing in wider adoption of best practices for mitigation in the food and agriculture sector could therefore have multiple payoffs for food security, including contributing to the stability of global food markets and providing new employment opportunities in the commercial agriculture sector, as well enhancing the sustainability of vulnerable livelihood systems.

This study encompasses research on the contribution of soil productivity and $C$ sequestration for food security and climate mitigation in two sample districts: Mustang and Bajhang. Mustang lies in the Chitwan Annapurna Landscape (CHAL) whereas Bajhang lies in the Sacred Kailash Landscape. The study aimed to assess the soil properties of both the sites, namely the total nitrogen (TN), exchangeable potassium (EK), available phosphorus (AP), cation exchange capacity (CEC), SOC, bulk density (BD) and the production level of local farmers. There is potential of up-scaling the study approach in other landscapes of the Hindu Kush Himalayan (HKH) where food security and mitigation potentials can be addressed simultaneously. The study adds to the information required for developing nationally appropriate mitigation action (NAMA) activities and also contributes to the nationally determined contributions (NDCs) of Nepal to formulate the mitigation goals and strategies as it also emphasizes the need to protect vulnerable ecosystems, and the need to ensure food security while mitigating climate change, as well as to contribute to the formulation of a national adaptation plan (NAP) which is in process in Nepal.

\section{Materials and Methods}

\subsection{Transect Selection}

Transects were selected to represent the major physiographic complexities in Nepal, ranging from the low lands and foot hills to the high altitude region. From the perspective of resource assessment, different management systems were also covered wherever possible such as protected forests, community forests, government forest, irrigated agricultural land, non-irrigated agricultural land, grassland/rangelands and agroforestry practices if any.

\subsection{Soil Sampling}

Soil samples were collected from seven transects each in Bajhang and Mustang (Figure 1a,b). The transects covered four land use types; barren land, agricultural land, orchard land/forest land and degraded shrub land. Altogether 28 plots (four land use types in each seven transects) were selected for the sample collection covering both districts, i.e., Bajhang and Mustang, along the Seti, and Kali Gandaki rivers respectively. Samples were taken from soil pits at two depths in each plot (i.e., $0-15 \mathrm{~cm}$ and 15-30 $\mathrm{cm}$ below the soil surface) with the pit made large enough to allow for taking loose samples and samples at the lower depth as well. From each depths "core samples" were collected by using a core sampler with a ring size of $50.8 \mathrm{~mm}$ diameter and $50 \mathrm{~mm}$ length (volume $\sim 100 \mathrm{~cm}^{3}$ ) for soil bulk density (BD) determination. Loose samples ( $500 \mathrm{~g})$ from both the depths and each sample plots were taken for the analysis of soil properties. 


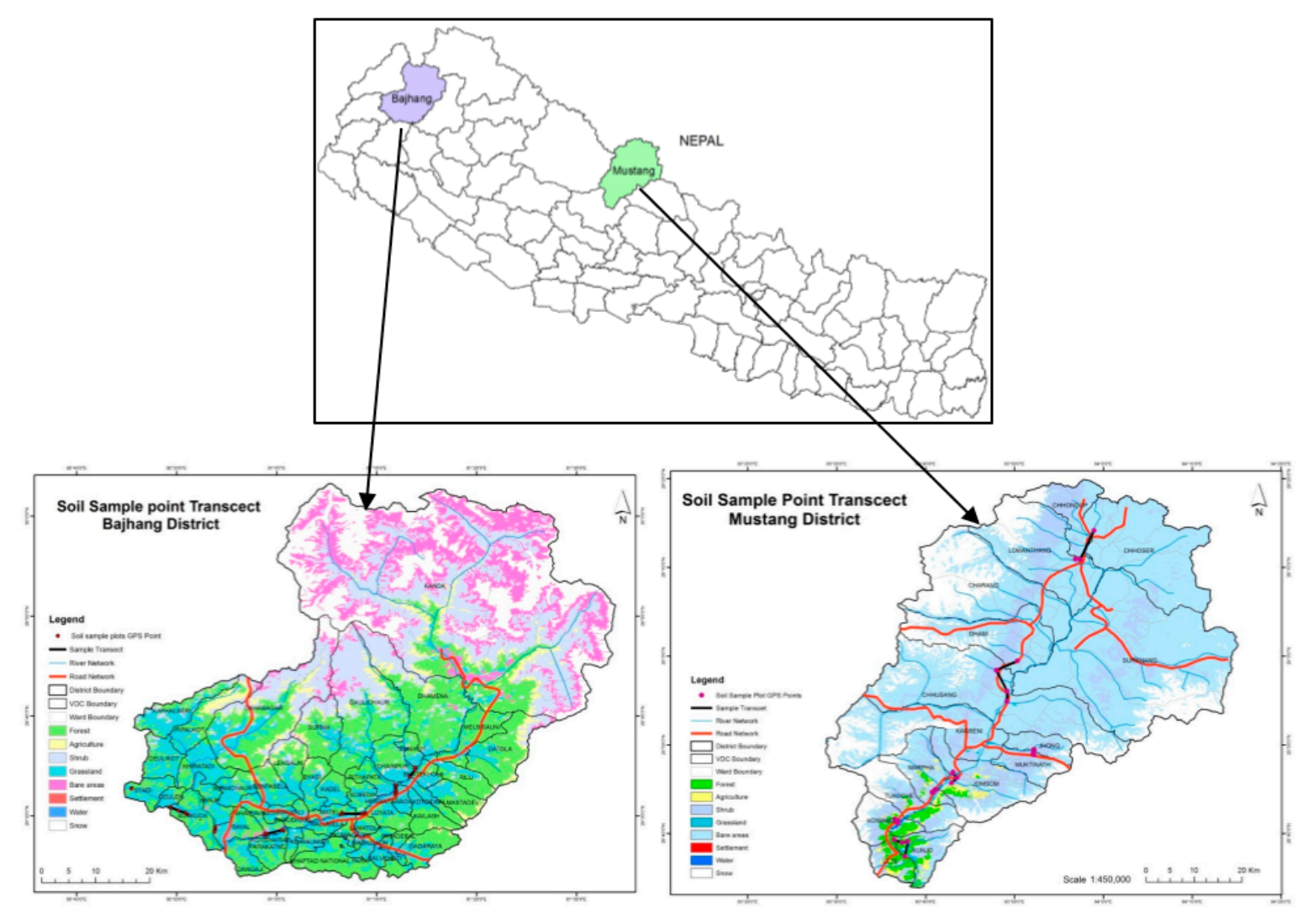

(a)

(b)

Figure 1. Study sites with sampling plots: (a) Sample points in Bajhang district; (b) Sample points in Mustang district.

A random sampling method along the transects was followed to collect soil samples. Further, stratification was achieved by dividing the transect survey line area into different strata based on the prior knowledge of the land use types and topographic positions.

The soil samples were transported in labeled and sealed plastic bags to Aquatic and Environment Center (AEC) laboratory at Kathmandu University, Dhulikhel, Kavre, Nepal for drying, grinding, sieving and analysis. Standard methods [8-14] were followed for the analysis of the physical and chemical parameters of the soil samples which are given below.

- Soil texture: Soil textural class was determined by a Soil hydrometer method [8].

- Bulk Density: Bulk density was determined by a Core method [9].

- Soil organic matter and organic C: Organic matter was determined by a Dry combustion method [10].

- $\quad \mathrm{pH}: \mathrm{pH}$ was determined using a pH Probe method 1:1 soil: water ratio [11].

- Total nitrogen: Total nitrogen was determined using a Kjeldahl method [12].

- Available phosphorus: Available phosphorous was determined using a Modified Olsen's method [13].

- Exchangeable potassium: Exchangeable potassium was determined using the Ammonium acetate method [14] followed by AAS.

The soil C stocks were quantified using Loss on Ignition method which basically exclude the carbonate as it accounts the biomass loss at the $550{ }^{\circ} \mathrm{C}$ temperature. 


\subsection{Survey and Questionnaire/Social Data Collection}

Household questionnaire surveys, key informants surveys and group discussions were held for social data collection. One key informant survey and six focus group discussions were carried out in each transect, from where the samples were collected. In the household questionnaire surveys, both open and closed ended questions were included. A well formatted questionnaire survey was prepared after the site visiting. Mostly senior persons and educated ones of the family were appointed in the survey. Most of the questions were related to agricultural and forest management systems, its farming systems and utilization systems, productivity of agricultural plots and its sufficiency to family members, change in climate and its local level impacts.

The objectives of the discussion included; existing farming practice, crop productivity and food security situation; Farmer's responses on their experience with current farming practices; Local experiences on climate change conditions and its impacts on soil fertility and existing forest land, agricultural land and bare lands use.

Key informants selected during the survey were ex-service holders, local teachers, social-mobilizers for queries related to the study. Similarly, for focus group discussion, which included five to 10 participants, mostly straight forward and open ended questions were raised. Teachers, local persons, experienced workers in agriculture and soil conservation, community forest chairman, and others participants who are engaged with related national and international non-governmental organizations (I/NGOs) were preferred for data collection during focus group discussion.

\subsection{Statistical Data Analysis}

The data generated from the laboratory analysis and those obtained from the field itself on forest bio-physical and soil properties were analyzed using the appropriate correlation and analysis of variance (ANOVA). The results derived were related with climate change mitigation and resource security issues in terms of soil fertility and nutrients.

\section{Results and Discussion}

\subsection{Results}

\subsubsection{Demographic Characteristics of Bajhang and Mustang}

Table 1 shows the general demographic characteristics of the study sites, i.e., Bajhang and Mustang. It also shows the literacy rates and land holding capacities of both districts.

Table 1. Social demographic characteristics of Bajhang and Mustang.

\begin{tabular}{ccccc}
\hline Districts & Total Population & Literacy Rate & Major Occupation & Land Holding Capacity \\
\hline Bajhang & 195,159 & $55.50 \%$ & Agriculture, Labor & $0.4-0.6$ ha \\
Mustang & 13,452 & $66.2 \%$ & Agriculture, Animal herding & From 0.1-0.2 up to 3 ha \\
& Source: CBS, 2011 [15] & & Source: Field data, 2015 \\
\hline
\end{tabular}

\subsubsection{Occupation}

The main occupation of the people of Mustang and Bajhang districts is agriculture, especially potato, barley and maize production in the lower altitudes. Lately, growing vegetables and apples has increased in Mustang whereas Bajhang is confined to traditional subsistence agriculture practices. Mustang, being a tourist destination, has the benefit of additional opportunities from tourism.

Generally, the average land holding capacity in the Bajhang district varies from 0.4 to 0.6 hectares (ha) per household. The variation of land holding capacity is seen to be affected by castes of the people and also equally due to altitudinal regions. In the Mustang district, the land holding capacity of each 
household varied a lot. People with a small land area only have less than a hectare of land, whereas people, mainly of the Chhongu village, on average owned 1.25 to 3 ha of land per household.

\subsubsection{Soil Properties}

- Soil physical properties of Bajhang and Mustang

The texture of the soil is one of the key characteristics considered for soil classification. Fertility levels of the soil along with water retention and aeration also depend on soil texture (Table 2).

Table 2. Soil texture of Bajhang and Mustang.

\begin{tabular}{lll}
\hline District & Soil Texture & Most Found Soil Texture \\
\hline Mustang & $\begin{array}{l}\text { Loam, silt loam, silty clay loam, sandy } \\
\text { clay loam and clay }\end{array}$ & $58.9 \%$ of the samples were found to be silt loam \\
\hline Bajhang & $\begin{array}{l}\text { Silt loam, sandy loam, sandy clay loam, } \\
\text { clay loam, clay and sandy clay }\end{array}$ & $82.1 \%$ of the samples were found to be clay \\
\hline
\end{tabular}

- Chemical parameters

The chemical characteristics were analyzed in the laboratory. The results are tabulated below (Table 3) and discussed in the subsequent paragraphs.

Table 3. Chemical and physical properties of soils in Bajhang and Mustang.

\begin{tabular}{ccccccc}
\hline District & Values & pH & OC (\%) & TN (\%) & AP (ppm) & EK (me/100 g) \\
\hline \multirow{3}{*}{ Bajhang } & Mean \pm St. error & $7.21 \pm 0.16$ & $2.47 \pm 0.17$ & $0.18 \pm 0.01$ & $111.34 \pm 10.05$ & $0.15 \pm 0.01$ \\
& Minimum & 5.29 & 0.20 & 0.04 & 10.94 & 0.03 \\
& Maximum & 9.09 & 7.69 & 0.68 & 359.70 & 0.38 \\
\hline \multirow{3}{*}{ Mustang } & Mean \pm St. error & $7.89 \pm 0.08$ & $2.60 \pm 0.25$ & $0.18 \pm 0.02$ & $77.43 \pm 9.41$ & $0.26 \pm 0.02$ \\
& Maximum & 8.81 & 8.56 & 0.8 & 361.20 & 0.79 \\
& Minimum & 5.65 & 0.51 & 0.02 & 1.49 & 0.05 \\
\hline
\end{tabular}

Notes: pH: Power of Hydrogen, OC: Organic Contents, TN: Total Nitrogen, AP: Available Phosphorus, EK: Exchangeable Potassium.

\section{Soil pH Value}

The soil provides plants with essential nutrients such as calcium $(\mathrm{Ca})$, nitrogen $(\mathrm{N})$, phosphorus $(\mathrm{P})$, potassium $(\mathrm{K})$, and magnesium $(\mathrm{Mg})$ which are affected by the acidity of the soil $(\mathrm{pH})$ [16]. In the case of strongly acidic soil, agricultural lime and animal manures can be applied to avoid a further increase in soil acidity. Most of the soil samples were found to be alkaline which lowers the availability of many soil nutrients such as iron, zinc, copper and manganese. So, in order to meet a healthy crop production quantity, efforts should be made to lower the $\mathrm{pH}$ of soil. According to Oosterbaan [17], the causes of soil alkalinity are natural or they can be man-made. The natural development is due to the presence of soil minerals producing sodium carbonate upon weathering. According to him, alkaline soils can be reclaimed with grass cultures, ensuring the incorporation of much acidifying organic material into the soil, and leaching of the excess sodium (Na). Deep ploughing and incorporating the calcareous sub-soil into the top-soil also help to normalize the acidity and alkalinity of the soil. It is also possible to reclaim alkaline soils by adding acidifying minerals such as pyrite $\left(\mathrm{FeS}_{2}\right)$. If necessary, gypsum (calcium sulphate, $\mathrm{CaSO}_{4}$ ) can also be applied as a source of $\mathrm{Ca}(++)$ ions. Oosterbaan [17] adds that in order to reclaim the soils properly, one needs prohibitively high of doses of amendments. Most efforts are therefore directed to improving the top layer only, as the top layer is most sensitive to structural deterioration [17]. 


\section{Total Nitrogen (TN)}

According to Silva and Uchida [17], a moderate amount of nitrogen is needed for all of the enzymatic reactions in a crop. Nitrogen is also a major part of the chlorophyll molecule and is therefore necessary for photosynthesis. $\mathrm{N}$ also improves the quality and quantity of dry matter in leafy vegetables and protein in grain crops [18]. $\mathrm{N}$ deficiency causes early maturity in some crops, which results in a significant reduction in yield and quality. In order to overcome such problem, TN can be increased by the continuous application of farmyard manure (FYM) [19], resulting in increases from $0.09 \%$ to $0.17 \%$ in the long-term application of FYM.

\section{Available Phosphorous (AP)}

One of the reasons for the level of $\mathrm{P}$ being high in most of the sampled soils could be the application of a large amount of organic manure on agricultural fields. Also, other nutrients, for example nitrogen, are lost in huge amounts through leaching, but not phosphorous. Also, according to Tisdale et al. [20], very little $\mathrm{P}$ is lost by crop removal, and therefore it can be understood that $\mathrm{P}$ added as fertilizer can accumulate in the soil for longer times than other nutrients [20].

\section{Exchangeable Potassium (EK)}

According to Silva and Uchida [18], unlike N and P, K does not form any vital organic compounds in the plant. However, the presence of $\mathrm{K}$ is vital for plant growth because $\mathrm{K}$ is known to be an enzyme activator that promotes metabolic activities [18]. It has also been shown to improve disease resistance in plants, improve the size of grains and seeds, and improve the quality of fruits and vegetables.

\section{Soil Carbon Stocks}

In comparison, agricultural and grass land soils of both the districts were similar to their respective forest soils in terms of the soil $C$ content. The lowest mean $C$ content was found to be in barren land for both the sites. Forests had the highest mean $C$ in Bajhang, and in Mustang agricultural land had the highest mean value of $C$ stored in soils (Table 4). According to Adams's [21] compiled work, forests soil have the capacity to store more than $100 \mathrm{t} \cdot \mathrm{ha}^{-1}$ of $C$ [21]. In our study, the $C$ stored by forest soils is low in both sites, suggesting that agriculture and grass lands are storing SOC more effectively. The significance values suggest that Bajhang has significantly different $C$ stock values in different land use types at a $1 \%$ level of significance where as Mustang has values that are significantly different at the $5 \%$ level of significance (Table 4 ).

Table 4. Soil organic carbon (SOC) stocks ${ }^{a}$ of soils in different land use types in Bajhang and Mustang (up to $30 \mathrm{~cm}$ depth).

\begin{tabular}{ccccc}
\hline Sites & Forest Land & Grass Land & Agricultural Land & Barren Land \\
\hline Bajhang & $53.61 \pm 5.81$ & $53.49 \pm 5.18$ & $48.81 \pm 7.54$ & $45.31 \pm 10.75$ \\
Mustang & $40.41 \pm 9.64$ & $33.92 \pm 8.49$ & $52.02 \pm 7.74$ & $32.50 \pm 6.39$ \\
ANOVA & F-Value & Significance & & \\
Bajhang & 0.959 & $0.419^{* *}$ & & \\
Mustang & 1.485 & $0.229 *$ & & \\
\hline \multicolumn{4}{r}{ a values are in t.ha ${ }^{-1}$; $^{*}$ significant at the 0.05 level; ** significant at the 0.01 level. }
\end{tabular}

\subsubsection{Change in Food Culture and Habits}

The mountain regions of Nepal which include districts such as Bajhang have a high capacity for the production of maize (Zea mays) and other cereal crops. Similarly, this place is highly fertile for "bethe" (Chenopodium album, Lamb's Quarter) and "Jau" (Hordeum vulgare, barley) production. However, nowadays, these crops have been replaced by rice (Oryza sativa), wheat (Triticum aestivum) and potato (Solanum tuberosum). 
Local persons of the study area explained that three decades ago, they rarely used domestic animals products and dependent on dairy products from these animals and went to the forest and pasture land to collect "bethe" for their meals. They also used to eat puffed maize or finger millet (Eleusine coracana) local-made bread for snacks. They explained that the meal has been replaced by wheat and rice in current decades. The snacks have also been replaced by instant noodles.

This change shows two parallel parts: one due to the change in monitory flow in households and the other due to changing culture with modern habits. Similarly, this replacement by modern food items is also due to ease of use and quick time requirements for their cooking.

One participant of the group discussion said that three to four decades ago, people of these areas rarely used to domestic animals for dairy products and had "Bethe" as well as "Jau" and "Fapar" (Fagopyrum esculentum, buckwheat) to prepare local breads as their major food items. However, nowadays, due to rice and wheat availability and preferences, they neither consume traditional food items nor can they cultivate an adequate amount of rice and wheat from their farm land.

\section{Discussion}

\subsection{Crops Production}

From the field surveys carried out in sampled Village Development Committees (VDCs) of the Bajhang and Mustang districts, a wide variation in crop production was found. There is also variation in the dominant species of forest trees. Efforts should be made to increase the production at the commercial scale through the application of scientific tools and techniques in agriculture. Appropriate management practices can be adopted to increase the area under production on existing farmland. Not only sustaining life but increasing productivity on existing agricultural land also avoids greenhouse gas emissions in numerous ways. Maintaining crop diversity in agricultural production is one key factor for productivity, as it enables risk management and preserves potentials for adaptation and change. Farmers should now learn the benefits of raising livestock rather than other herds as it provides multiple goods, such as food, wool, hides, etc. In case of famine, when crops are not sufficient to ensure food safety, livestock can be used as food. Livestock may also provide manure, which can be used to fertilize cultivated soils, which increases soil productivity. On the other hand, in an agricultural system based only on raising livestock, food has to be bought from other farmers, and wastes produced cannot be easily disposed of. Production has many functions, and diversity is the foundation of such production.

\subsection{Climate Change Mitigation and SOC}

In order to allow soils to store organic $\mathrm{C}$ effectively and contribute to climate change mitigation, efforts should be made to increase the C-containing capacity of soils. According to International Federation of Organic Agriculture Movements (IFOAM 2009), with the right type of agriculture, emissions leading to climate change can be minimized and the capacity of nature to mitigate climate change can be harnessed to sequestrate significant quantities of atmospheric carbon dioxide-especially in the soil. The potential for soil sequestration depends greatly on a number of variables including the soil type, climate, land-use history, and farming system adopted-especially the availability and quantity of C-rich components used in the system such as compost, manure, perennial plants, pastures and trees [22].

According to Chan [23], there are a wide range of management options and farming practices that can increase SOC levels by either increasing inputs or decreasing losses. Inputs can be increased by direct additions of organic materials, composts, manure and other recycled organic materials. There are many other management practices that can be implemented which can increase the soil organic C-containing capacity which can ultimately assist in mitigating climate change such as retaining forest slash and crop residues, applying fertilizer to overcome nutrient deficiencies, selecting cropping, forest or pasture systems that will maximize plant growth, minimizing cultivation disturbance to 
reduce mineralization and erosion losses and modifying grazing management to maintain pasture cover, thereby minimizing erosion losses and maximizing organic input to soil [23].

\subsection{Climate Change Mitigation, Food Security and Land Use Type}

From the study, both in Bajhang and Mustang, the highest mean SOC was found to be in the forest land, followed by grass land, and the lowest in the barren land. The mean SOC data obtained from the study sites suggest that forests and grass land have a high potential to sequester $\mathrm{C}$ and ultimately contribute to mitigating climate change. However, the variation in SOC according to land use types was found to be non-significant. Past studies also suggest that land use change from forest to abandoned farmland significantly reduced the organic $C$ accumulation in the soil [24]. The results of the present study provide insight into the potential benefits of forest and grass land to act as $C$ sinks, indicating that when agricultural practices are stopped, the abandoned farmlands are led to a shift in vegetation composition in the sense that agricultural productions are replaced by shruband grass-dominated communities. Such shifts boost the capability of the atmospheric $\mathrm{C}$ to be fixed in these types of ecosystems. Consequently, the potential of forest and grassland in $\mathrm{C}$ sequestration should be considered for appropriate management in order to maximize $\mathrm{CO}_{2}$ sequestering as well as to balance $\mathrm{CO}_{2}$ emissions.

On the basis of climate change mitigation by $\mathrm{C}$ sequestration, forests and grass land are the optimum type of land use. If food security is to be considered, the best land use practice is agriculture. In order to create a win-win situation for both nature and humans, agroforestry seems to be a possible option so that both nature and humans can endure and grow in harmony. Other studies also suggest agroforestry as an alternative to just forestry or just agriculture [25]. Like a few other land use options, agroforestry has real potential to contribute to food security, climate change mitigation and adaptation, while preserving and strengthening the environmental resource base of rural landscapes. It has a key role to play in landscape-level mitigation schemes under the Reducing Emission from Deforestation and forest Degradation (REDD+) concepts. For the local people whose livelihoods are threatened by climate change and food security, agroforestry offers a pathway toward more resilient livelihoods [26].

The correlation analysis (Table 5) revealed that for the Bajhang district, SOC was highly positively correlated with TN and EK and negatively correlated with AP. This trend was not, however, seen in the Mustang district, although EK was highly positively correlated with TN and AP.

Table 5. Correlation analysis among SOC and soil properties in each district.

\begin{tabular}{|c|c|c|c|c|c|c|c|c|}
\hline \multicolumn{5}{|c|}{ Bajhang } & \multicolumn{4}{|c|}{ Mustang } \\
\hline & SOC & TN & AP & EK & SOC & TN & AP & EK \\
\hline SOC & 1 & 0.869 ** & $-0.265^{*}$ & $0.377^{* *}$ & 1 & 0.239 & -0.002 & 0.1 \\
\hline $\mathrm{TN}$ & $0.869^{* *}$ & 1 & $-0.326^{*}$ & $0.329 *$ & 0.239 & 1 & $0.297 *$ & $0.435^{* *}$ \\
\hline $\mathrm{AP}$ & $-0.265^{*}$ & $-0.326^{*}$ & 1 & 0.063 & -0.002 & 0.297 * & 1 & 0.509 ** \\
\hline EK & $0.377^{* *}$ & 0.329 * & 0.063 & 1 & 0.1 & $0.435^{* *}$ & $0.509 * *$ & 1 \\
\hline
\end{tabular}

\section{Conclusions}

From this study, we have seen that agriculture is the main occupation of the people of both the Bajhang and Mustang districts, which is the basis for their survival. Moreover, agriculture is the supplier of nutrition to human beings and it affects the daily life of people in many ways, both directly and indirectly.

Most of the soils from our study areas were alkaline which requires careful management in order to increase the availability of certain soil nutrients such as iron (Fe), zinc (Z), copper $(\mathrm{Cu})$ and manganese (Mn), the availability of which is hindered by alkaline soils. Most of the soils in both the districts were found to contain low total $\mathrm{N}$ which is essential to meet a desired level of crop production. 
The K contents of most of the samples were also low. These nutrients should be augmented through various organic and inorganic external sources which can be prepared locally or can even be bought. Available P was very high in most of the study sites. This is presumably due to application of organic manures for agricultural purposes and the fact that, unlike other nutrients, $\mathrm{P}$ is not lost readily through run-off. The organic C contents of almost all the sampled soils were low and need to be increased through the addition of organic manure and compost.

The soil data of both study sites indicate that the soils are not sequestering SOC to their full potential. Efforts should be made to increase $C$ sequestration and one of the easiest ways to do so is the application of FYM which results in high microbial activity and vegetation growth. The nutrient-rich manure, apart from being used to supply the soils with deficient nutrients, can also be used to promote $C$ sequestration by maintaining soil organic matter through catalyzing floral and faunal activities in the soil. Also, the correlation of SOC with other soil parameters such as TN, AP, EK, pH and CEC should also be considered. From the study, it was found that SOC showed a significant negative correlation with $\mathrm{pH}$, bulk density and AP, whereas a positive correlation was found with TN, EK and CEC, which were also significant (Table 5). As these nutrients' contents in the soil can be altered to some extent by human efforts, they can be increased or decreased accordingly to favor the SOC content in the soil by soil amendments using FYM and Bio-char. With climate change and food security both being global as well as local issues in the study sites, strategies to increase SOC in agriculture land especially will not only contribute to GHG mitigation but also to enhancing food production that helps to address food security issues [27], particularly in remote mountain landscapes through introducing high-value cash crops, i.e., "Ground apple" (Smallanthus sonchifolius, Yacon) and "Kiwifruit" (Actinidia chinensis).

Acknowledgments: Special thanks go to the International Center for Integrated Mountain Development (ICIMOD) for providing this opportunity by funding this research in relation to the soil productivity, food security and SOC. The authors are thankful to the AEC Lab, Kathmandu University, for the timely analysis of soil samples in the lab. Thanks also go to the team members during the field study for their support during sampling and spatial and statistical analysis of the report. I also want to acknowledge the contribution of Raju Gurung, District Soil Conservation Office, Dadeldhura and Santosh Sherchan, ACAP, Lomanthang, who guided and provided crucial guidelines during the field data collection.

Author Contributions: Him Lal Shrestha led the study and contributed in the formulation of the research, field data collection, data analysis and articulation of the study together with finalizing the manuscript preparation. Trishna Singh Bhandari contributed during the field data collection and drafting the paper at the first level. Bhaskar Singh Karky contributed in streamlining the study and feedback on the draft of manuscript. Rajan Kotru provided his critical suggestions on the study and manuscript.

Conflicts of Interest: The authors declare no conflict of interest. The funding sponsors had no role in the design of the study; in the collection, analyses, or interpretation of data; in the writing of the manuscript, and in the decision to publish the results.

\section{References}

1. Lal, R. Soil Carbon Sequestration Impacts on Global Climate Change and Food Security. Science 2004, 304, 1623-1627. [CrossRef] [PubMed]

2. Dahal, N.; Bajracharya, M.R. Prospects of Soil Organic Carbon Sequestration: Implications for Nepal's Mountain Agriculture. J. For. Livelihood 2010, 9, 45-56. [CrossRef]

3. Kaini, B.R. Increasing crops production in Nepal. In Proceedings of the 24th National Summer Crops Research Workshop on Maize Research and Production, Kathmandu, Nepal, 28-30 June 2004; Sherchan, D.P., Adhikari, K., Batsa, B.K., Sharma, D., Eds.; National Maize Research Programme (NMRP) and Nepal Agriculture Research Council (NARC): Kathmandu, Nepal, 2004; pp. 15-19.

4. Bajracharya, R.M.; Sitaula, B.K.; Shrestha, B.M.; Awasthi, K.D.; Balla, M.K.; Singh, B.A. Soil Organic Carbon Status and Dynamics in the Central Nepal Middle Mountains. J. Inst. For. 2004, 12, 28-44.

5. Shrestha, B.; Brown, S. Land use dynamics and intensification. In Proceedings of the Challenges in Mountain Resource Management in Nepal: Processes, Trends, and Dynamics in Middle Mountain Watershed. Workshop Proceedings, Kathmandu, Nepal, 10-12 April 1995; Schreier, H., Brown, B., Shah, P.B., Eds.; International Centre for Integrated Mountain Development (ICIMOD): Kathmandu, Nepal, 1995. 
6. United Nations Environment (UNEP). The Benefits of Soil Carbon: Managing Soils for Multiple Economic, Societal and Environmental Benefits; UNEP Year Book; United Nations Environment (UNEP): Nairobi, Kenya, 2012; p. 28.

7. Food and Agriculture Organization (FAO). Food Security and Agricultural Mitigation in Developing Countries: Options for Capturing Synergies; Food and Agriculture Organization (FAO): Rome, Italy, 2009; p. 84.

8. Gee, G.W.; Bauder, J.W. Particle Size Analysis. In Methods of Soil Analysis, Part 1 Physical and Mineralogical Methods, 2nd ed.; Klute, A., Ed.; American Society of Agronomy Monograph No. 9; ASA-SSSA, Inc.: Madison, WI, USA, 1986; pp. 383-411.

9. Blake, G.R.; Hartge, K.H. Bulk density. In Methods of Soil Analysis, Part 1 Physical and Mineralogical Methods, 2nd ed.; Page, A.L., Ed.; American Society of Agronomy Monograph No. 9; ASA-SSSA, Inc.: Madison, WI, USA, 1986; pp. 363-376.

10. Nelson, D.W.; Sommers, L.E. Total Carbon, Organic Carbon and Organic Matter. In Methods of Soil Analysis Part 2 Chemical and Microbiological Properties, 2nd ed.; Page, A.L., Miller, R.M., Keeney, D.R., Eds.; American Society of Agronomy Monograph No. 9; ASA-SSSA, Inc.: Madison, WI, USA, 1982; pp. 539-580.

11. McLean, E.O. Soil $\mathrm{pH}$ and lime requirement. In Methods of Soil Analysis Part 2 Chemical and Microbiological Properties, 2nd ed.; American Society of Agronomy Monograph No. 9; ASA-SSSA, Inc.: Madison, WI, USA, 1982; pp. 199-224.

12. Bremner, J.M.; Mulvaney, C.S. Nitrogen Total. In Methods of Soil Analysis Part 2 Chemical and Microbiological Properties, 2nd ed.; Page, A.L., Miller, R.M., Keeney, D.R., Eds.; American Society Agronomy Monograph No. 9; ASA-SSSA, Inc.: Madison, WI, USA, 1982; pp. 595-610.

13. Olsen, S.R.; Sommers, L.E. Phosphorous. In Methods of Soil Analysis Part 2 Chemical and Microbiological Properties, 2nd ed.; Page, A.L., Miller, R.M., Keeney, D.R., Eds.; American Society Agronomy Monograph No. 9; ASA-SSSA, Inc.: Madison, WI, USA, 1982; pp. 403-416.

14. Rhoades, J.D. Cation Exchange Capacity. In Methods of Soil Analysis Part 2 Chemical and Microbiological Properties, 2nd ed.; Page, A.L., Miller, R.M., Keeney, D.R., Eds.; American Society Agronomy Monograph No. 9; ASA-SSSA, Inc.: Madison, WI, USA, 1982; pp. 149-158.

15. Tripathi, B.P. Review on Acid Soil and its Management in Nepal; Lumle Seminar Paper; Pokhara: Kathamndu, Nepal, 1999; Volume 99/1.

16. Oosterbaan, R.J. Lecture Note on Alkaline-Sodic Soils and Acid-Sulphate Soils; International Course on Land Drainage (ICLD) and International Institute for Land Reclamation and Improvement (ILRI): Wageningen, The Netherlands, 2003.

17. Silva, J.A.; Uchida, R. Plant Nutrient Management in Hawaii's Soils, Approaches for Tropical and Subtropical Agriculture; College of Tropical Agriculture and Human Resources, University of Hawaii: Manoa, HI, USA, 2000.

18. Regmi, A.P.; Pandey, S.P.; Joshy, D. Effects of Long-Term Application of Fertilizers and Manure on Soil Fertility and Crop Yields in Rice-Rice-Wheat Cropping System in Nepal, Long-Term Soil Fertility Experiments; Paper Series 6; Rice-Wheat Consortium for the Indo-Gangetic Plains: New Delhi, India, 2000; pp. 120-138.

19. Tisdale, S.L.; Nelson, W.L.; Beaton, J.D. Soil Fertility and Fertilizers; MacMillan Publishers Co.: New York, NY, USA, 1985.

20. Adams, J. Estimates of Pre-anthropogenic Carbon Storage in Global Ecosystem Types, Oak Ridge National Laboratory. 1997. Available online: http://www.esd.ornl.gov/projects/qen/carbon3.html (accessed on 31 December 2016).

21. Columbia Broadcast System (CBS). National Population and Housing Census 2011; National Report; Central Bureau of Statistics, Government of Nepal: Kathmandu, Nepal, 2011.

22. International Federation of Organic Agriculture Movements (IFOAM). The Contribution of Organic Agriculture to Climate Change Mitigation; International Federation of Organic Agriculture Movements (IFOAM), EU Group: Bonn, Germany, 2009.

23. Chan, Y. Increasing Soil Organic Carbon of Agricultural Land, Prime Fact 735; Department of Primary Industries: New South Wales, Australia, 2008.

24. Zuazo, V.H.; Rodriguez, C.R.; Tavira, S.C.; Martinez, J.R.M. Linking Soil Organic Carbon Stocks to Land-use Types in a Mediterranean Agroforestry Landscape. J. Agric. Sci. Technol. 2014, 16, 667-679. 
25. Mbow, C.; Noordwijk, M.V.; Luedeling, E.; Neufeldt, H.; Minang, P.A.; Kowero, G. Agroforestry Solutions to Address Food security and Climate Change Challenges in Africa; Science Direct; World Agroforestry Centre (ICRAF): Nairobi, Kenya, 2014; Volume 6, pp. 61-67.

26. Lal, R. Societal Value of soil carbon. J. Soil Water Conserv. 2014, 69, 186A-192A. [CrossRef]

27. IUSS Working Group WRB. World Reference Base for Soil Resources 2014. International Soil Classification System for Naming Soils and Creating Legends for Soil Maps; World Soil Resources Reports No. 106; Food and Agriculture Organization (FAO): Rome, Italy, 2014.

(c)

(C) 2017 by the authors. Licensee MDPI, Basel, Switzerland. This article is an open access article distributed under the terms and conditions of the Creative Commons Attribution (CC BY) license (http:/ / creativecommons.org/licenses/by/4.0/). 